\title{
PEMANFAATAN MEDIA GAMBAR BERSERI UNTUK MEMPERKAYA KEMAMPUAN MENULIS NARATIF BAHASA INGGRIS SISWA KELAS IX MTS. NW NURUL WATHON PENGEMBUR LOMBOK TENGAH
}

\author{
Ika Rama Suhandra \\ Universitas Islam Negeri Mataram \\ ikaramasuhandra@gmail.com
}

\begin{abstract}
Abstrak: Penguasaan bahasa Inggris sebagai bahasa resmi internasional merupakan tuntutan bagi siswa agar mampu bersaing di era globalisasi. Masyarakat di daerah destinasi wisata seperti Lombok membutuhkan penguasaan Bahasa Inggris yang baik agar memudahkan mereka untuk mencari lapangan pekerjaan. Oleh karenanya siswa di sekolah harus mendapatkan pembelajaran Bahasa Inggris yang baik agar memiliki kompetensi yang memadai. Tujuan pengabdian ini adalah untuk meningkatkan kemampuan menulis narasi bahasa Inggris bagi siswa kelas IX melalui pemanfaatan gambar berseri. Metode pengabdian yang digunakan adalah dengan pengabdian tindakan kelas (PTK) dengan partisipan sebanyak 24 siswa kelas IX. Hasil pengabdian menunjukkan bahwa pemanfaatan media gambar berseri dalam pembelajaran bahasa Inggris dapat meningkatkan kemampuan menulis naratif dalam Bahasa Inggris.
\end{abstract}

Kata kunci: gambar berseri, bahasa Inggris, kemampuan menulis

\begin{abstract}
Mastery of English as an official international language is a demand for students to be able to compete in the era of globalization. The residents in tourist destination areas such as Lombok need to master good English in order to be easier in finding jobs. Therefore students in schools must get good English learning in order to have adequate competence. The purpose of this community service activity is to improve the ability to write English narratives for students of class IX through the use of serial images. The method used was classroom action research with 24 students as participants in IX grade. The results show that the use of serial image media in learning English can improve the ability to write narratives in English.
\end{abstract}

Keywords: picture series, English, writing skill

\section{Pendahuluan}

Madrasah Tsanawiyah (MTs) Nurul Wathon adalah salah satu madrasah swasta yang terdapat di Kabupaten Lombok Tengah tepatnya di kecamatan Pujut desa Pengembur. Madrasah ini adalah satu-satunya madrasah Tsanawiyah yang terdapat di desa ini. Madrasah ini tergolong sangat sederhana karena disamping gedungnya sederhana, murid-muridnya juga tidak terlalu banyak. Madrasah ini tepatnya berada sekitar tujuh kilometer dari jalan raya atau jalan utama yang menghubungkan Bandara Internasional Lombok-Kuta. Sebagai salah satu sekolah swasta di kabupaten Lombok Tengah, sekolah ini menghadapi kendala sama halnya dengan sekolah swasta lainnya yang ada di Kabupaten Lombok Tengah. Persoalan klasik seperti infrastruktur dan minimnya pendanaan serta fasilitas penunjang sekolah lainnya adalah beberapa dari permasalahan yang ada di sekolah ini.

Berdasarkan hasil observasi dan wawancara dengan kepala madrasah (5 April 2017), disamping persoalan-persoalan tersebut diatas, ada satu hal lainnya yang membuat sekolah maupun madrasah di sekitar Lombok Tengah merasa galau, yaitu terkait dengan persoalan bahasa, khususnya bahasa Inggris. Kepala madrasah menjelaskan bahwa, Lombok Tengah 
sebagai salah satu daerah favorit tujuan wisata, memiliki banyak peluang dan kesempatan untuk membuka lapangan kerja bagi masyarakat umum. Tingginya, persaingan mengharuskan setiap sekolah/madrasah untuk bekerja ekstra keras khususnya untuk menghasilkan lulusan atau output yang berkualitas. Penguasaan bahasa Inggris adalah merupakan salah satu prasarat untuk menghadapi persoalan tersebut. Semakin bagus bahasa Inggris lulusan maka semakin terbuka lapangan kerja bagi mereka. Senada dengan pernyataan kepala sekolah tersebut diatas, guru mata pelajaran bahasa Inggris juga mengungkapkan bahwa kemampuan bahasa inggris siswa di MTs. Nurul Wathon masih tergolong rendah. Indikasinya adalah siswa jarang ada yang mampu berkomunikasi dan menulis aktif dengan menggunakan bahasa inggris meskipun itu dalam proses pembelajara bahasa inggris sekalipun.

Untuk mengatasi persoalan tersebut diatas, dibutuhkan media pembelajaran yang berkualitas disamping metode pembelajaran yangt baik untuk merangsang kreatifitas kebahasaan siswa khususnya yang berkaitan dengan keterampilan menulis siswa. Salah satu media pembelajaran yang cocok dengan situasi ini adalah dengan menggunakan media gambar berseri. Gambar berseri adalah gambar dengan rangkaian kegiatan atau cerita yang disajikan secara berurutan. Siswa berlatih mendeskripsikan setiap gambar, hasil deskripsi dari setiap gambar apabila dirangkai akan menjadi suatu karangan yang utuh (Arsyad, 2009: 119). Media ini dianggap baik karena dapat 1) membantu siswa dalam mengingat nama benda atau orang yang mereka lihat; 2) membantu mempercepat siswa dalam memahami materi, 3) membantu siswa dalam memahami konsep-konsep dari materi yang dipelajari khususnya materi yang berkaiatan dengan bahasa Inggris.

\section{Metode}

Metode yang digunakan pada pelaksanaan kegiatan pengabdian ini adalah pengabdian tindakan kelas (classroom action research). Pengabdian tindakan kelas dapat didefinisikan sebagai suatu pengabdian tindakan (action research) yang dilakukan oleh guru yang sekaligus sebagai pengabdi di kelasnya atau bersama-sama dengan orang lain (kolaborasi) dengan jalan merancang, melaksanakan dan merefleksikan tindakan secara kolaboratif dan partisipatif yang bertujuan untuk memperbaiki atau meningkatkan mutu (kualitas) proses pembelajaran di kelasnya melalui suatu tindakan (treatment) tertentu dalam suatu siklus. Pengabdian tindakan kelas termasuk pengabdian kualitatif meskipun data yang dikumpulkan bisa saja bersifat kuantitatif, dimana uraiannya bersifat deskriptif dalam bentuk kata-kata, pengabdi merupakan instrument pertama dalam pengumpulan data, proses sama pentingnya dengan produk. Pengabdian yang dilakukan untuk menyelesaikan masalah pembelajaran di kelas ini, menggambarkan bagaimana suatu teknik pembelajaran diterapkan dan bagaimana hasil yang diinginkan dapat tercapai. Dengan begitu perhatian pengabdi diarahkan kepada pemahaman bagaimana berlangsungnya suatu kejadian atau efek dari suatu tindakan. Tindakan yang diambil dalam pengabdian ini berupa penggunaan media gambar pada pembelajaran keterampilan menulis naratif dalam Bahasa Inggris. 
Pada pengabdian kali ini, pengabdi menggunakan prosedur Kurt Lewin. Kurt Lewin adalah penemu PTK pertama kali yang menyatakan bahwa dalam setiap siklusnya terdiri dari langkah - langkah sebagai berikut : 1) Perencanaan (planning). 2) Aksi atau tindakan (Acting). 3) Observasi (observing) 4) Refleksi (Reflecting).

Tahapan pertama dalam model Kurt Lewin adalah menyusun perencanaan (planning). Pada tahap ini kegiatan yang harus dilakukan adalah: (1) membuat Rencana Pelaksanaan Pembelajran (RPP). (2) mempersiapkan fasilitas dari sarana pendukung yang diperlukan di kelas. (3) mempersiapkan instrument untuk merekam dan menganalisis data mengenai proses dan hasil tindakan. Model Kurt Lewin pada tahap kedua adalah melaksanakan tindakan (acting), pada tahap kedua adalah melaksanakan tindakan yang telah dirumuskan dalam RPP dalam situasi yang aktual, yang meliputi kegiatan awal, kegiatan inti dan penutup. Selanjutnya untuk tahap ketiga yakni melaksanakan pengamatan (observing). Pada tahap ini, yang harus dilakukan pengabdi adalah: (1). Mengamati perilaku siswa-siswi dalam mengikuti kegiatan pembelajaran. (2) memantau kegiatan diskusi atau kerjasama antar siswa-siswi dalam kelompok. (3) mengamati pemahaman tiap-tiap anak dalam penguasaan materi pembelajaran yang telah dirancang sesuai dengan tujuan PTK. Pada tahap keempat yaitu melakukan refleksi (Reflecting). Pada tahap ini yang harus dilakukan penulis adalah: (1) mencatat hasil observasi (2) mengevaluasi hasil observasi (3) menganalisis hasil pembelajaran. (4) mencatat kelemahankelemahan untuk dijadikan bahan penyusun rancangan siklus berikutnya sampai tujuan PTK dapat dicapai.

Secara keseluruhan, empat tahapan dalam PTK tersebut membentuk suatu siklus PTK yang digambarkan dalam bentuk spiral. Untuk mengatasi suatu masalah, mungkin diperlukan lebih dari satu siklus. Siklus-siklus tersebut saling berkaitan dan berkelanjutan. Pengabdian tindakan kelas dilaksanakan pada bulan Juni-Oktober 2017. Lokasi pelaksanaan kegiatan pengabdian masyarakat ini dilakukan di MTs Nurul Wathon desa Pengembur Kabupaten Lombok Tengah. Subyek pengabdian ini adalah siswa kelas IX MTs. Nurul Wathon desa Pengembur Kabupaten Lombok Tengah, yang terdiri dari 24 siswa.

Variabel-variabel pengabdian yang dijadikan titik incar untuk menjawab permasalahan yang dihadapi yaitu: 1. Variabel input: Siswa Kelas IX MTs. Nurul Wathon Pengembur Lombok Tengah. 2. Variabel proses: Penerapan Media Gambar Berseri 3. Variabel output: Kemampuan menulis naratif siswa

Model yang digunakan dalam pengabdian tindakan kelas ini adalah model Kurt Lewin yang menyatakan bahwa dalam satu siklus terdiri atas empat langkah pokok yaitu: (1) Perencanaan (Planning), (2) tindakan (acting), (3) observasi (observing),dan (4) refleksi (reflecting).Sebelum melakukan PTK, terlebih dahulu melakukan observasi awal untuk (1) menemukan masalah; (2) melakukan identifikasi masalah; (3) menentukan "batasan masalah", (4) menganalisis masalah dengan menentukan faktor-faktor yang diduga sebagai penyebab utama terjadinya masalah; (5) merumuskan gagasan-gagasan pemecahan masalah dengan merumuskan identifikasi Masalah "hipotesis-hipotesis tindakan" sebagai pemecahan, (6) menentukan hipotesis tindakan pemecahan masalah, (7) merumuskan judul perencanaan kegiatan pembelajaran berbasis PTK. Pengabdian ini direncanakan dalam dua siklus. Pada setiap 
siklus akan diukur hasil karya siswa dan dianalisis setiap kekurangan dari pelaksanaan pembelajaran. Kemudian merencanakan kembali kegiatan pembelajaran untuk menghilangkan kekurangan yang ada pada siklus sebelumnya. Tahap-tahap yang ditempuh dalam pengabdian tindakan kelas adalah sebagai berikut : 1) Perencanaan. Pada tahap ini pengabdi merencanakan serangkaian kegiatan yang akan diterapkan di kelas pada saat pengabdian berlangsung. Adapun kegiatan yang dilakukan pada tahap perencanaan yaitu membuat rancangan pembelajaran (RPP), membuat format observasi, menyiapkan perangkat pembelajaran berupa materi pembelajaran bahasa Inggris, menyiapkan lembar kerja yang akan digunakan oleh siswa pada proses pembelajaran, menyiapkan media. 2) Pelaksanaan Tindakan, langkah selanjutnya bagi pengabdi adalah pelaksanaan. Pada tahap ini perencanaan yang sudah dibuat pengabdi akan dilaksanakan dalam kegiatan pembelajaran. Tahap pengamatan atau observasi dilakukan bersamaan dengan pelaksanaan tindakan. Pada tahap ini pengabdi dibantu oleh guru mata pelajaran atau guru kelas untuk mencatat semua hal yang diperlukan dalam pengabdian berupa pengumpulan data-data. 3) Observasi. Dalam tahap pengamatan ini ada tiga data yang dibutuhkan dalam pengabdian untuk mengetahui apakah kriteria keberhasilan sudah tercapai atau belum tercapai. Ketiga data tersebut adalah : 1) Hasil tes belajar siswa tentang pemahaman menulis bahasa Inggris. Data ini diperoleh dengan cara pengabdi melakukan evaluasi menggunakan tes tulis yang dikembangkan dalam tahap rencana dan diselesaikan oleh siswa setelah akhir tindakan. Berdasarkan tes pengabdi dapat mengetahui kriteria keberhasilan. 2) Data aktivitas guru selama pembelajaran perbaikan. Data ini diperoleh dari hasil pengamatan, pengamat menggunakan lembar pengamatan aktivitas guru. Data ini digunakan untuk mengetahui ketercapaian criteria keberhasilan 3) Data aktivitas siswa selama pembelajaran perbaikan. Data ini diperoleh dari hasil pengamatan, pengamat menggunakan lembar pengamatan aktivitas siswa. Data ini digunakan untuk mengetahui ketercapaian kriteria keberhasilan. 4) Refleksi. Pada kegiatan refleksi dilakukan analisis terhadap hasil tes, observasi, dokumentasi dan wawancara untuk mengetahui kegagalan atau masalah yang dialami selama proses pembelajaran berlangsung dan kemudian dicarikan solusi yang efektif (replanning) yang sesuai untuk mengatasi kegagalan tersebut untuk diimplementasikan pada siklus selanjutan yaitu siklus II.

Sumber data dalam PTK ini adalah : a) Siswa. Sumber data dari siswa berasal dari siswa kelas IX MTs. Nurul Wathon Pengembur Lombok Tengah yang terdiri dari 24 siswa. b) Guru. Sumber data dari aktivitas guru berasal dari guru mata pelajaran Bahasa Inggris kelas IX MTs. Nurul Wathon Pengembur Lombok Tengah.

Dalam pelaksanaan Pengabdian Tindakan Kelas, ada dua jenis data yang dapat dikumpulkan oleh pengabdi, yakni : Data kuantitatif (nilai hasil belajar siswa) dan Data kualitatif yaitu berupa informasi berbentuk kalimat yang memberi gambaran tentang ekspresi siswa dalam pembelajaran. Teknik pengumpulan data yang digunakan antara lain : 1) Wawancara. Wawancara digunakan sebagai teknik pengumpulan data apabila pengabdi ingin melakukan studi pendahuluan untuk menemukan permasalahan yang harus diteliti, dan juga apabila pengabdi ingin mengetahui hal-hal dari responden yang lebih mendalam dan jumlah respondennya sedikit/kecil. Adapun yang akan diwawancarai pada pengabdian ini adalah semua 
yang ada di MTs. Nurul Wathon baik guru, maupun siswanya. Dalam wawancara ini diharapkan dapat diketahui secara jelas adanya Peningkatan keterampilan menulis siswa dengan menggunakan media gambar berseri. 2) Observasi. Observasi adalah kegiatan pengamatan (pengambilan data) untuk memotret seberapa jauh efek tindakan telah mencapai sasaran. Metode observasi yang digunakan yaitu jenis observasi partisipasi aktif. Dimana dalam observasi ini pengabdi ikut melakukan apa yang dilakukan oleh narasumber. Observasi ini digunakan pengabdi untuk memperoleh data tentang proses pembelajaran baik aktivitas guru maupun siswa dengan menggunakan lembar observasi yang memuat beberapa kriteria pengukuran yang telah ditetapkan. Dalam hal ini, pengabdi banyak menggunakan jenis observasi langsung, upaya yang pengabdi gunakan adalah untuk menggali data tentang keadaan guru dan anak dalam kelas, sarana dan prasarana. Observasi dilakukan dengan menggunakan lembar observasi pelaksanaan pembelajaran yang diisi oleh guru kelas. 3) Dokumentasi. Metode dokumentasi yaitu mencari data mengenai hal-hal atau variabel yang berupa catatan, transkrip, buku, surat kabar, majalah, notulen, rapat, agenda, dan sebagainya.Dalam pengabdian ini metode dokumentasi digunakan untuk mengumpulkan data-data yang ada pada lembaga sekolah sebagai penunjang data . Data-data tersebut meliputi aktivitas siswa dalam proses balajar mengajar dan penerapan media gambar berseri. 4) Tes. Salah satu yang diukur dalam pengabdian ini adalah peningkatan kemampuan keterampilan menulis bahasa Inggris siswa yang diperoleh dengan menggunakan instrument tes. Pengambilan data dengan cara tes prestasi belajar yaitu menghendaki jawaban atas hasil belajar siswa pada saat penerapan media gambar berseri. Dalam menggunakan tes, pengabdi memberikan sebuah topik sebagai objek tulisan mereka.

Pada Pelaksanaan kegiatan tindakan kelas ini, digunakan analisis deskripsi kualitatif, yaitu suatu metode pengabdian yang bersifat menggambarkan kenyataan atau fakta sesuai dengan data yang diperoleh dengan tujuan untuk mengetahui hasil belajar yang dicapai siswa juga untuk mengetahui respon siswa terhadap kegiatan serta aktivitas siswa selama proses pembelajaran berlangsung. Tujuan dari analisis ini adalah untuk mendeskripsikan kegiatan siswa selama proses belajar mengajar. Analisis deskriptif yang dilakukan sebagai berikut: 1) Analisis Deskriptif Kualitatif, Analisis deskriptif kualitatif adalah memberikan produksi kepada variabel yang disebutkan sesuai dengan kombinasi yang sebenarnya. Teknik ini digunakan untuk menganalisis data yang bersifat kualitatif. Analisis deskriptif kualitatif ini diperoleh dari data kualitatif yang dikumpulkan dalam pengabdian yang meliputi: a. Lembar observasi guru, b. Lembar observasi siswa, dan c. Hasil wawancara guru dan siswa, 2) Analisis Deskriptif Kuantitatif. Kuantitatif yaitu statistik yang berfungsi untuk mendeskripsikan atau memberi gambaran terhadap obyek yang diteliti melalui data sampel atau populasi sebagai adanya tanpa melakukan analisis dan membuat kesimpulan yang berlaku untuk umum. Teknik ini digunakan untuk menganalisis data yang bersifat kuantitatif. Yang termasuk data kuantitatif adalah hasil belajar siswa. Untuk menganalisa hasil belajar siswa setelah proses pembelajaran setiap siklus dilakukan dengan memberikan evaluasi yang berupa soal uji kompetensi. 3. Data Ketuntasan Siswa. Berdasarkan petunjuk pelaksanaan belajar mengajar, bahwa tingkat pencapaian untuk tes formatif adalah $85 \%$, maka pengabdi menganggap bahwa peenggunaan strategi resiprokal 
dikatakan berhasil dalam meningkatkan kemampuan keterampilan menulis jika siswa mampu menyelesaikan dan memenuhi ketuntasan belajar yaitu minimal $85 \%$ atau standar nilai sekitar 70 dengan kriteria tingkat keberhasilan belajar.

Dalam PTK ini yangakan dilihat indikator kinerjanya selain siswa adalah guru, karena guru merupakan fasilitator yang sangat berpengaruh terhadap kinerja siswa. 1 . Siswa: a. Tes : ratarata nilai ulangan harian, b. Observasi: keaktifan siswa dalam proses belajar mengajar Bahasa Inggris. 2. Guru: a. Dokumentasi : kehadiran dan kegiatan belajar mengajar siswa dalam bentuk data. b. Observasi : aktivitas guru dalam proses pembelajaran

\section{Hasil dan Pembahasan}

Pelaksanaan kegiatan tindakan kelas yang dilakukan pengabdi yang dibantu oleh guru mata pelajaran bahasa Inggris kelas IX MTs. NW Nurul Wathon Pengembur Lombok Tengah merupakan upaya untuk meningkatkan kemampuan menulis naratif siswa dengan menerapkan perangkat pembelajaran atau media gambar berseri (picture series). Berikut ini adalah pelaksanaan tindakan pengabdian yang dilaksanakan pada siswa kelas IX MTs. NW Nurul Wathon Pengembur Lombok Tengah.

\section{Sebelum Tindakan Kelas (Pra Siklus)}

Pengabdi telah melakukan observasi di kelas IX MTs. NW Nurul Wathon Pengembur Lombok Tengah dan bekerja sama dengan guru / wali kelas IX. Obyek pengabdian tindakan kelas ini adalah siswa kelas IX MTs. NW Nurul Wathon Pengembur Lombok Tengah, sebanyak 24 siswa yang terdiri 9 siswa laki-laki dan 15 siswa perempuan. Pada pelaksanaan pra siklus ini pengabdi bertindak sebagai observer sedangkan guru kelas IX bertindak sebagai pengajar. Pada tanggal 29 Juli 2017 diadakan test awal kemampuan menulis pada siswa kelas IX. Hal tersebut bertujuan untuk mengetahui kemampuan awal menulis siswa. Hasil tes kemampuan awal dijadikan pedoman untuk mengetahui keadaan siswa sebelum diberi tindakan dan nantinya dijadikan pembanding setelah diterapkannya media gambar berseri dalam pembelajaran Bahasa Inggris.

Untuk mengetahui kemampuan menulis naratif, siswa diminta menulis dengan tema pasar. Sehingga dapat diketahui apakah siswa tersebut mengalami kesulitan menulis atau hanya kurang berlatih menulis sehingga sering mengalami kesalahan dalam menulis karangan naratif. Berdasarkan hasil wawancara yang pengabdi lakukan kepada guru kelas IX, diketahui bahwa siswa kelas IX memiliki nilai yang rendah dalam mata pelajaran Bahasa Inggris khususnya dalam aspek menulis. Siswa menganggap bahwa mata pelajaran Bahasa Inggris terutama menulis adalah pelajaran yang tidak mudah, sehingga mereka kurang termotivasi untuk mengembangkan kemampuan menulisnya. Siswa merasa bahwa menulis dalam bahasa inggris membutuhkan keterampilan dan banyak persyaratan yang harus dikuasai diantaranya; penguasaan kosakata, struktur bahasa serta kemampuan nalar dan wacana yang baik. Sehingga hal ini berdampak pada kemampuan menulis siswa yang kurang terasah dengan baik dan pada nilai bahasa Inggris banyak siswa yang nilainya kurang dari KKM pada saat itu yaitu rata-ratanya adalah 70 . 
Kemampuan menulis naratif pada pelajaran bahasa Inggris sebelum dilaksanakannya tindakan, jumlah siswa yang telah tuntas mencapai KKM pada pra siklus adalah $50 \%$ atau 12 siswa dari 24 siswa yang masuk dan jumlah siswa yang belum mencapai KKM 50 \% atau 12 siswa dari 24 siswa yang masuk. Dengan data tersebut pengabdi dan guru kelas menyimpulkan bahwa rata-rata kemampuan menulis siswa kelas IX mata pelajaran bahasa Inggris pada pra siklus di kelas IX masih belum tuntas.

Berdasarkan data yang didapat pengabdi dari guru mata pelajaran bahasa Inggris, maka harus diadakan tindakan yang inovatif untuk meningkatkan kemampuan menulis siswa. Pada saat melakukan tindakan pengabdi bertindak sebagai observer sementara guru bahasa Inggrisnya bertindak langsung sebagai pengajar yang menggunakan media gambar berseri dalam mengajar. Sebelum melakukan tindakan, pengabdi dan guru berdiskusi tentang media gambar berseri, terutama bagaimana penerapannya di dalam kelas. Demikian halnya juga dengan sistem penilaian, dan materi yang akan diberikan. Hal tersebut dilakukan dengan harapan bahwa media yang diberikan dapat meningkatkan kemampuan menulis naratif siswa kelas IX MTs. NW Nurul Wathon Pengembur.

\section{Deskripsi Setiap Siklus}

a. Siklus I

\section{1) Tahap Perencanaan}

Berdasarkan kesepakatan dengan guru bahasa Inggris kelas IX tindakan yang akan dilakukan untuk meningkatkan kemampuan menulis siswa kelas IX MTs. NW Nurul Wathon Pengembur Lombok Tengah adalah dengan menggunakan media gambar berseri. Perencanaan yang dilakukan adalah sebagai berikut : a) Pembuatan Rencana Pelaksanaan Pembelajaran (RPP) sebagai rencana kegiatan yang akan dilakukan guru dan siswa dalam proses pembelajaran. Rencana pelaksanaan Pembelajaran dialokasikan dalam 2 jam pelajaran atau 2 x 35 menit. Rencana Pelaksanaan Pembelajaran siklus I terdapat pada lampiran 1. b) Guru mempersiapkan media dan prasarana yang akan dipergunakan dalam kegiatan pembelajaran. Guru dan pengabdi menyediakan macam - macam gambar berseri berupa cerita anak. c) Persiapan instrumen yang akan digunakan dalam pengabdian ini, diantaranya lembar observasi guru, lembar observasi keaktifan siswa dan wawancara

\section{2) Pelaksanaan Tindakan}

Tahapan selanjutnya setelah perncanaan persiapan media dan instrumen adalah pelaksanaan tindakan dengan menggunakan media gambar berseri. Pada pelaksanaan tindakan ini pengabdi melaksanakan keseluruhan Rencana Pelaksanaan Pembelajaran (RPP) siklus I. Rincian dan deskripsi nyata dari setiap pertemuan adalah sebagai berikut : Pelaksanaan tindakan siklus I dilaksanakan pada hari Senin, kamis dan senin berikutnya bertepatan dengan tanggal 7, 10, dan 14 Agustus 2017. Jam pelajaran 3-4 dengan alokasi waktu 2x35 menit. Pada siklus I materi yang diajarkan adalah tentang kegiatan sehari-hari yang dilakukan dirumah dan sekitarnya. Kegiatan awal yang dilakukan guru pengabdi yaitu mengkondisikan kelas dan mempersiapkan peserta didik baik fisik maupun psikis untuk melaksanakan proses pembelajaran. Pembelajaran diawali dengan berdoa dan presensi siswa. Setelah itu guru 
mengajak peserta didik untuk bernyanyi bersama agar siswa lebih semangat untuk memulai pembelajaran. Guru menyampaikan tujuan serta indikator pembelajaran yang akan dicapai pada peserta didik. Pada kegiatan inti aktivitas yang dilalui meliputi:

a) Eksplorasi

Pada kegiatan eksplorasi guru pengabdi menggali kemampuan awal siswa dengan bertanya jawab tentang kegiatan-kegiatan sehari-hari siswa baik dirumah maupun disekitarnya. Selanjutnya siswa memperhatikan penjelasan guru tentang aktivitas sehari-hari. Kegiatan ini dilakukan baik pada pertemuan pertama, kedua dan ketiga.

b) Elaborasi

Pada hari pertama, guru melakukan kegiatan elaborasi dimana guru membagi siswa menjadi 6 kelompok untuk mendiskusikan tentang gambar berseri yang berisi kegiatan seharihari serta cerita anak. Guru menjelaskan tugas yang harus dikerjakan dalam kelompok. Kemudian masuk pada materi yaitu menginstruksikan kepada masing-masing kelompok untuk menulis cerita dalam bahasa Inggris sesuai dengan gambar berseri yang dibagikan. Setelah dianggap paham dan tidak ada pertanyaan, siswa dan kelompoknya kemudian mulai menulis dan berdiskusi. Guru berkeliling memperhatikan siswa menulis, dan apabila ada kesulitan, siswa diminta bertanya sementara guru menjawab dan memberi contoh jawaban pertanyaan yang disampaikan siswa tersebut. Pada saat siswa-siswa menulis, kolaborator (pengabdi) menilai kemampuan menulis peserta didik dengan mengisi unjuk kerja yang sudah dipersiapkan. Ketika kegiatan menulis sedang berlangsung, guru kadang-kadang memberikan masukan tentang materi bacaan serta teknik penulisan, serta memberikan peserta didik waktu beberapa menit untuk berdiskusi dan melihat apakah mereka menunjukkan ketertarikan dan memahami tentang poin-poin yang dijelaskan tersebut. Siswa mencatat hasil diskusi dan mempresentasikan hasil diskusi. Guru menunjuk salah satu siswa untuk mempresentasikan dan menilai kemampuan menulis berdasarkan hasil diskusi kelompok. Setelah itu kemudian guru memberikan penilaian dan melakukan evaluasi terhadap hasil menulis keseluruhan siswa. Kegiatan seperti ini berlangsung juga di pertemuan kedua dan ketiga, hanya saja bedanya adalah pada pertemuan kedua dan ketiga, siswa tidak lagi melaksanakan aktivitas secara berkelompok melainkan dilakukan secara individu. Pada pertemuan pertama, kedua, dan ketiga, topiknya juga berbeda.

c) Konfirmasi

Kegiatan konfirmasi dilakukan guru untuk menggabungkan kemampuan awal siswa dan materi baru yang diberikan oleh guru. Guru menilai kemampuan menulis siswa pada saat berkelompok. Konfirmasi yang dilakukan dengan cara guru dan siswa bersama - sama menyimpulkan materi pelajaran yang telah selesai dipelajari. Guru memberikan kesempatan pada peserta didik untuk bertanya apabila ada yang belum paham mengenai materi. Pada akhir pembelajaran siswa dan guru melakukan refleksi pembelajaran yaitu dengan umpan balik dari guru pengabdi mengenai kegiatan pembelajaran yang telah dilaksanakan. Kemudian guru memberi peserta didik tugas untuk ditulis di rumah. Guru menutup pembelajaran dengan salam. (Kegiatan ini juga dilakukan dipertemuan kedua dan ketiga). 


\section{3) Observasi}

Kegiatan observasi dilaksanakan pada saat proses pembelajaran berlangsung (pertemuan pertama, kedua, dan ketiga). Observasi dilakukan untuk memperoleh data. Observasi juga digunakan untuk memperoleh data kesesuaian pelaksanaan pembelajaran dengan rencana pelaksanaan pembelajaran (RPP) yang telah disusun dalam perencanaan sebelumnya. Observasi dilakukan oleh pengabdi bertindak sebagai observer.

Pengamatan dilakukan tidak hanya difokuskan kepada guru namun juga dilakukan pada aktivitas siswa dalam pembelajaran. Sehingga pengamatan dilakukan menyeluruh pada semua aspek baik dari aspek siswa maupun kegiatan guru pada saat kegiatan berlangsung. Berdasarkan observasi yang telah dilakukan, dapat disimpulkan bahwa guru belum menguasai kelas sepenuhnya dan belum bisa mengalokasikan waktu dengan baik. Dalam kegiatan pembelajaran siklus I masih terdapat siswa yang masih melakukan kesalahan-kesalahan dalam menulis. Dimana siswa masih menulis tanpa memperhatikan tanda baca dan masih banyak yang menulis tidak berdasarkan kaidah atau struktur bahasa Inggris yang baik dan benar. Disamping itu, pengabdi dan kolaborator mengadakan tes untuk mengetahui prestasi siswa atau kemampuan menulis siswa dimana, hasilnya adalah sebagai berikut.

Tabel 1. Daftar Nilai Menulis Naratif Siswa Kelas IX MTs. NW Nurul Wathon Pengembur Lombok Tengah Siklus 1

\begin{tabular}{ccc}
\hline No & Nama Siswa & Siklus 1 \\
\hline 1 & Bq. Masiah & 41,66 \\
2 & Bq. Masitah & 54,2 \\
3 & Heny Susanti & 70,82 \\
4 & Husnul Laili & 62,49 \\
5 & Ika Astuti & 54,15 \\
6 & Khaerul Yaqin & 62,49 \\
7 & L. Muhammad Kirana & 41,66 \\
8 & Liana Astuti Purnama & 33,32 \\
9 & Martina Yuliantini & 70,82 \\
10 & Maskur Firdaus & 45,82 \\
11 & Muhammad Imran & 62,49 \\
12 & Nurita Dewi Ratnasari & 41,66 \\
13 & Rabiatul Hasanah & 70,82 \\
14 & Raehatul Jannah & 45,82 \\
15 & Raumin & 41,66 \\
16 & Rukmini Hardianti & 54,2 \\
17 & Sahdiamin & 70,82 \\
18 & Sailum & 62,49 \\
19 & Shintia Maramis & 87,39 \\
20 & Siti Marmah & 72,85 \\
21 & Hendi handika & 72,00 \\
22 & Afandi Yusril & 85,00 \\
23 & L. Suparman & 90,50 \\
24 & Muh. Yusuf & 72,00 \\
\hline & 58,73 \\
\hline
\end{tabular}

Dari tabel dan grafik di atas dapat dilihat bahwa kemampuan menulis kelas IX MTs. NW Nurul Wathon Pengembur Lombok Tengah masih rendah. Hal ini dibuktikan dengan banyaknya 
siswa yang nilai kemampuan menulisnya belum mencapai KKM yang di tetapkan yaitu 70 . Baru $50 \%$ atau 128 siswa yang sudah mencapai KKM dan belum mencapai indikator pencapaian yang ditetapkan yaitu $80 \%$. Dengan demikian pengabdian perlu dilanjutkan untuk mencapai indikator pencapaian yang ditetapkan.

\section{4) Refleksi}

Berdasarkan pengamatan yang telah dilakukan selama proses pembelajaran dan hasil diskusi kolaborasi dengan guru pengabdi dengan guru kelas XI dinyatakan bahwa guru masih belum maksimal dalam melaksanakan proses pembelajaran bahasa Inggris khususnya kemampuan menulis dengan media gambar berseri. Hal tersebut dapat dilihat pada hasil pengamatan siswa bahwa masih ada siswa yang kesulitan dan ramai pada saat pembelajaran berlangsung. Hal tersebut dapat terjadi karena guru belum bisa menciptakan situasi dan kondisi pembelajaran yang nyaman dan menyenangkan bagi siswa. Guru juga belum menegur dengan tegas kepada siswa yang ramai sendiri dan tidak mempaerhatikan penjelasan guru serta mengganggu temannya. Akibatnya siswa yang ramai tersebut tidak mengetahui cara menulis yang baik. Saat siswa tersebut disuruh memperlihatkan hasil tulisannya, siswa tersebut hanya diam dan menyatakan belum menulis.

Berdasarkan uraian diatas dapat diketahui bahwa kekurangan siswa dalam mengikuti pembelajaran kemampuan menulis naratif dengan media gambar berseri pada mata pelajaran bahasa Inggris yaitu : a) Banyak siswa yang ramai sendiri b) Siswa masih kesulitan dalam penggunaan tanda baca, merangkai kata menjadi kalimat yang baik. c) Siswa kurang dalam penguasaan kosa kata d) Siswa masih kurang memahami tentang penggunaan struktur kalimat atau grammar, e) Siswa kurang kontribusi dalam mengerjakan tugas kelompok d) Siswa kurang memperhatikan penjelasan guru.

Kekurangan dalam proses pembelajaran: a) Suasana pembelajaran kurang efektif dan menyenangkan. b) Pengalokasian waktu yang kurang tepat. c) Penjelasan guru kurang menarik minat siswa sehingga siswa kurang memperhatikan pelajaran d) Guru dalam bimbingan diskusi kurang menyeluruh pada semua siswa dalam pelaksanaan kegiatan diskusi kelompok.

Berdasarkan hasil refleksi siklus I yang masih terdapat kekurangan maka pengabdian dilanjutkan ke tahap siklus II. Hal ini dikarenakan bahwa pada siklus I nilai kemampuan menulis siswa kelas IX baru mencapai $50 \%$.

\section{b. Siklus II}

\section{1) Tahap perencanaan}

Berdasarkan hasil refleksi siklus I yang masih banyak kekurangan perlu direvisi dan hasilnya akan menjadi acuan untuk pelaksanaan tindakan pada siklus II. Pembelajaran difokuskan pada siswa dan pembelajaran pada siswa dijelaskan semaksimal mungkin sehingga kemampuan menulis naratif siswa meningkat. Rencana pelaksanaan Siklus II ini dilaksanakan untuk memperbaiki tindakan pada siklus I. Perencanaan sikus II berpedoman pada hasil refleksi sikus I. Tindakan yang harus diperbaiki pada sikus II adalah : a) Pengelolaan dan penguasaan kelas yang baik b) Guru membimbing siswa yang mengalami kesulitan dalam menulis naratif. c) guru menganjurkan siswa untuk membawa kamus bahasa Inggris-Indonesia, d) Pengalokasian waktu. e) Mengkondisian siswa agar aktif merespon guru dalam proses pembelajaran. Siklus II 
dilaksanakan pada hari rabu tanggal 13 Agustus 2017 selama 2 jam mata pelajaran atau 2×35 menit pada jam 3-4 atau jam 09.30 - 10.40. Siklus II ini bertujuan untuk memperbaiki kekurangan - kekurangan pada tindakan siklus I. Materi yang diajarkan pada sikus II ini adalah tentang cerita pendek yang memuat cerita anak. Perencanaan yang dilakukan pada silus II adalah : a) Pembuatan Rencana Pelaksanaan Pembelajaran (RPP) dimasukan hasil refleksi siklus I dengan tujuan perbaikan. Rencana pelaksanaan Pembelajaran dialokasikan dalam 2 jam pelajaran atau 2 × 35 menit dengan materi cerita anak. b) Guru mempersiapkan media dan prasarana yang akan dipergunakan dalam kegiatan pembelajaran. Guru menyediakan media gambar berseri yang sesuai materi cerita anak. c) Persiapan instrumen yang akan digunakan dalam pengabdian ini, diantaranya lembar observasi guru, lembar observasi keaktifan siswa dan wawancara.

\section{2) Pelaksanaan Tindakan}

Tahapan selanjutnya setelah perncanaan persiapan media dan instrumen adalah pelaksanaan tindakan dengan menggunakan media gambar berseri (picture series). Pada pelaksanaan tindakan ini pengabdi melaksanakan keseluruhan Rencana Pelaksanaan Pembelajaran (RPP) siklus II. Rincian dan deskripsi nyata dari setiap pertemuan adalah sebagai berikut : Pelaksanaan tindakan siklus II dilaksanakan pada hari senin, selasa, dan rabu yang bertepatan dengan tanggal 13 Agustus 2017. Jam pelajaran 3-4 dengan alokasi waktu 2x35 menit. Pada siklus II materi yang diajarkan adalah tentang cerita pendek. Kegiatan awal yang dilakukan guru pengabdi yaitu mengkondisikan kelas dan mempersiapkan peserta didik baik fisik maupun psikis untuk melaksanakan proses pembelajaran. Pembelajaran diawali dengan berdoa dan presensi siswa. Guru menyampaikan tujuan serta indikator pembelajaran yang akan dicapai pada peserta didik pada siklus II. Pada kegiatan inti aktivitas yang dilalui meliputi:

a) Eksplorasi

Pada kegiatan eksplorasi guru pengabdi menggali kemampuan awal siswa dengan bertanya jawab tentang pengetahuan siswa tentang cerita pendek. Selanjutnya siswa memperhatikan penjelasan guru tentang cerita pendek khususnya cerita anak yang berkaitan dengan cerita kedaerahan maupun nasional.

b) Elaborasi

Pada pertemuan pertama di kegiatan elaborasi guru membagi kelompok menjadi 6 kelompok untuk diskusi tentang cerita rakyat. Guru menjelaskan tugas yang harus dikerjakan dalam kelompok. Kemudian masuk pada materi yaitu kan contoh-contoh cerita rakyat; guru menyebutkan beberapa cerita rakyat seperti sangkuriang, temelak mangan, tegodek-godek dll. Pada saat guru menjelaskan materi pembelajaran, kolaborator menulis proses dan aktivitas yang terjadi di dalam kelas dengan mengisi unjuk kerja atau lembar observasi yang sudah dipersiapkan. Setelah guru menjelaskan tentang cerita pendek yang berkaitan dengan cerita rakyat, guru kemudian mengisnstruksikan kepada para siswa dan kelompoknya untuk memilih satu cerita rakyat untuk dikerjakan berkelompok. Ketika proses kerja kelompok berlangsung, guru berkeliling kelas untuk memantau situasi dan membantu siswa jika mereka merasa kesulitan dalam proses menulis. Setelah sekian lama proses menulis berlangsung, guru kemudian menyuruh semua kelompok untuk berhenti menulis. Selanjutnya, masing-masing 
kelompok disuruh untuk mempresentasikan hasil kelompok mereka. Guru mendengarkan bacaan perwakilan masing-masing kelompok kemudian melakukan koreksi terhadap kesalahan yang dilakukan siswa baik yang berhubungan dengan penggunaan diksi, struktur kalimat, maupun kesalahan lainnya yang berkaitan dengan keterampilan menulis. kegiatan ini juga dilakukan oleh guru namun pada pertemuan kedua dan ketiga, siswa tidak lagi bekerja secara berkelompok melainkan bekerja secara individu.

c) Konfirmasi

Konfirmasi yang dilakukan dengan cara guru dan siswa bersama - sama menyimpulkan materi pelajaran yang telah selesai dipelajari. Guru memberikan kesempatan pada peserta didik untuk bartanya apabila ada yang belum paham mengenai materi. Pada akhir pembelajaran siswa menerima penguatan berupa pujian bagi siswa yang memiliki tulisan yang baik dan bagus dan memberi motivasi bagi siswa yang masih belum aktif. Guru melakukan refleksi pembelajaran yaitu dengan umpan balik dari kolaborator mengenai kegiatan pembelajaran yang telah dilaksanakan. Kemudian guru memberi peserta didik tugas untuk membaca di rumah . Guru menutup pembelajaran dengan salam.

\section{3) Observasi}

Berdasarkan observasi yang telah dilakukan, guru sudah menguasai kelas sepenuhnya dan dapat mengalokasikan waktu dengan baik. Kesalahan-kesalahan dalam menulis seperti yang berhubungan dengan kosa kata, tanda baca, pemilihan diksi dll sudah tidak dilakukan. Pada siklus II terdapat peningkatan kemampuan siswa dibandingkan siklus I dan pra siklus. Hal tersebut dapat dilihat dari hasil tes kemampuan menulis yang sudah dilakukan siswa. Pada siklus I terdapat 12 siswa (50\%) yang mendapat nilai diatas 70 sesuai KKM. Sedangkan pada siklus II terdapat 24 siswa (100 \%) yang mendapat nilai diatas 70 atau diatas KKM. Dari data di atas dapat diketahui bahwa terdapat peningkatan dari siklus II dibandingkan siklus I. Hal tersebut dapat dilihat pada table dibawah ini.

Tabel 2. Daftar Nilai Menulis Naratif Siswa Kelas IX MTs. NW Nurul Wathon Pengembur Lombok Tengah Siklus II

\begin{tabular}{cccc}
\hline No & Nama Siswa & Siklus 1 & Siklus 2 \\
\hline 1 & Bq. Masiah & 41,66 & 70,82 \\
2 & Bq. Masitah & 54,2 & 72.30 \\
3 & Heny Susanti & 70,82 & 83.32 \\
4 & Husnul Laili & 62,49 & 74.98 \\
5 & Ika Astuti & 54,15 & 70.82 \\
6 & Khaerul Yaqin & 62,49 & 83.32 \\
7 & L. Muhammad Kirana & 41,66 & 72.49 \\
8 & Liana Astuti Purnama & 33,32 & 70.65 \\
9 & Martina Yuliantini & 70,82 & 79.15 \\
10 & Maskur Firdaus & 45,82 & 74.98 \\
11 & Muhammad Imran & 62,49 & 79.15 \\
12 & Nurita Dewi Ratnasari & 41,66 & 76.65 \\
13 & Rabiatul Hasanah & 70,82 & 83.32 \\
14 & Raehatul Jannah & 45,82 & 74.98 \\
15 & Raumin & 41,66 & 72.49 \\
16 & Rukmini Hardianti & 54,2 & 70,82 \\
17 & Sahdiamin & 70,82 & 79.15
\end{tabular}




\begin{tabular}{cccc}
18 & Sailum & 62,49 & 83.32 \\
19 & Shintia Maramis & 87,39 & 90.50 \\
20 & Siti Marmah & 72,85 & 80.00 \\
21 & Hendi handika & 72,00 & 85.00 \\
22 & Afandi Yusril & 85,00 & 90.00 \\
23 & L. Suparman & 90,50 & 92.00 \\
24 & Muh. Yusuf & 72,00 & 80.15 \\
\hline & 58,73 & 1819.56 \\
\hline & Nilai Rata-Rata & 1409,65 & 75.81 \\
\hline
\end{tabular}

Dari tabel dan grafik di atas dapat kita lihat terjadi kenaikan nilai siswa yang mencapai KKM. Pada siklus II terdapat kenaikan nilai pada jumlah siswa yang mendapat nilai di atas KKM, pada siklus I hanya terdapat $50 \%$ atau 12 siswa yang mencapai KKM dan pada siklus II menjadi $100 \%$ atau 24 siswa yang mencapai KKM, maka perlu pengabdian dihentikan dikarenakan hasil pengabdian pada siklus II sudah mencapai target yang ditetapkan pengabdi sebesar $80 \%$.

\section{4) Refleksi}

Berdasarkan pengamatan yang telah dilakukan selama proses pembelajaran dan hasil diskusi kolaborasi dengan guru pengabdi dengan guru kelas IX menyatakan bahwa guru pengabdi sudah maksimal dalam melaksanakan proses pembelajaran bahasa Inggris khususnya kemampuan menulis dengan penggunaan gambar berseri. Hal tersebut dapat dilihat pada hasil pengamatan siswa bahwa secara keseluruhan siswa merasa senang dan siswa telah mampu menulis dengan baik dan benar. Hal tersebut dapat terjadi karena guru pengabdi membimbing siswa dalam pemahaman dalam menulis dan kondisi pembelajaran sudah nyaman dan menyenangkan bagi siswa. Guru juga sudah menegur dengan tegas kepada siswa yang ramai sendiri dan tidak mempaerhatikan penjelasan guru serta mengganggu temannya, sehingga tercipta suasana kondusif dalam pembelajaran dan peserta didik juga mampu mengikuti pembelajaran dengan baik.

Berdasarkan uraian di atas dapat disimpulkan bahwa : a) Siswa sudah mampu menulis dengan baik dan benar dan mampu mengaplikasikan aspek-aspek keterampilan menulis seperti kohesi, koherensi, tanda baca, pemilihan diksi yang benarserta sikap pembelajaran sudah baik dan meningkat dari siklus I. b) Secara keseluruhan siswa merasa senang dalam proses pembelajaran sehingga suasana pembelajaran efektif dan menarik minat siswa dalam pelajaran bahasa Inggris khususnya kemampuan menulis dengan penggunaan media gambar, c) Siswa mampu bekerja sama dengan teman - temannya. d) Guru sudah maksimal menciptakan situasi pembelajaran yang menyenangkan sehingga tidak ada lagi siswa yang menganggap pelajaran menulis itu membosankan.

Berdasarkan hasil refleksi siklus II dapat direfleksikan bahwa dalam pelajaran bahasa Inggris khususnya kemampuan menulis sudah menunjukkan keberhasilan yang optimal. Berdasarkan uraian di atas, kemampuan menulis naratif pada mata pelajaran bahasa Inggris dengan penggunaan media gambar berseri adalah seluruh siswa kelas IX mampu menuli dengan baik dan benar.

Bersumber dari data di atas dapat direfleksikan bahwa pembelajaran bahasa Inggris khususnya kemampuan mnulis dengan penggunaan media gambar berseri menunjukkan 
keberhasilan yang optimal. Berdasarkan hasil refleksi siklus II sudah mencapai target yaitu nilai 70. Siswa yang melebihi KKM $\geq 70$ terdapat $100 \%$ atau 24 siswa yang masuk maka pengabdian dapat diterima dan dihentikan. Meningkatnya kemampuan menulis dalam pelajaran bahasa Inggris dapat dilihat dari hasil pengabdian berikut : 1 . Pada siklus I dari 24 siswa yang masuk terdapat 12 siswa (50 \%) yang mendapatkan nilai diatas 70 (KKM). 2. Pada siklus II ada peningkatan kemampuan menulis siswa dari siklus I. Dari kemampuan menulis 24 siswa, kesemuanya memiliki nilai diatas 70 (KKM) atau 100\%.

\section{Kesimpulan}

Berdasarkan hasil pengabdian diketahui bahwa terdapat peningkatan kemampuan menulis. Hal tersebut diindikasikan dari perolehan nilai kemampuan menulis siswa pada siklus 1 dimana terdapat 12 siswa (50 \%) yang mendapat nilai di atas KKM 70. Sementara rata-rata kemampuan siswa atau rata-rata nilai tes siswa pada siklus pertama adalah 58.73. Ini artinya bahwa nilai rata-rata tersebut masih dibawah KKM yang dipersyaratkan sekolah sebesar 70. Sementara pada siklus II, semua siswa (100\%) mendapat nilai diatas 70 atau diatas nilai KKM yang dipersyaratkan oleh sekolah dan nilai rata-rata keseluruhan siswa pada keterampilan menulisnya adalah 75.81. Berdasarkan fakta tersebut diatas maka dapat diambil kesimpulan bahwa pengajaran menulis naratif dalam bahasa Inggris menggunakan media gambar mampu mengakselerasi kemampuan menulis siswa kelas IX MTs. NW Nurul Wathon Pengembur Lombok Tengah.

\section{Daftar Pustaka}

Angkowo, R., dan Kosasih, A. 2007. Optimalisasi Media Pembelajaran. Jakarta: Grasindo. Arsyad, Azhar. 2009. Media Pembelajaran. Jakarta: Rajawali Press.

Borg, W.R \& Gall, M.D. Gall. 1989. Educational Research: An Intoduction, Fifth Edition. New York: Longman.

Enro, Fachruddin Ambo. 1988. Dasar-dasar Keterampilan Menulis. Jakarta: Depdikbud P2LPTK. Iskandar, dan Sukini. 2009. Bahasa Indonesia 4: Untuk Kelas 4 SD/MI. Jakarta: Depdiknas.

Keraf, Gorys. 2007. Argumentasi dan Narasi. Jakarta: Gramedia Pustaka Umum. Nurgiyantoro, Burhan. 2001. Penilaian dalam Pengajaran Bahasa Indonesia dan Sastra. Yogyakarta: BPFE.

Porwadarminta. 1984. Kamus Besar Bahasa Indonesia. Jakarta: Balai Pustaka.

Sadiman, Arief S dkk. 2011. Media Pendidikan: Pengertian, Pengembangan, dan Pemanfaatannya. Jakarta: Rajawali Press.

Sanaky, Hujair . 2009. Media Pembelajaran. Yogyakarta: Safiria Insania Press.

Sudjana, Nana dan Achmad Rivai. 2009. Media Pembelajaran (Penggunaan dan Pembuatannya). Bandung: Sinar Baru Algensindo.

Sugiyono. 2012. Metode Penelitian Pendidikan. Bandung: Alfabeta.

Tarigan, Henry Guntur. 2008. Menulis Sebagai Suatu Keterampilan Berbahasa. Bandung: Angkasa. The Liang Gie. 1992. Pengantar Dunia Karang-Mengarang. Yogyakarta: Liberty Yogyakarta.

Tizen, Ella Farida. 2008. Gambar Berseri Sebagai Media Pembelajaran. [online]. Tersedia: http://suaraguru.wordpress.com/2015/03/gambar-berseri.html [6 Maret 2015]

Zainurrahman. 2011. Menulis dari Teori Hingga Praktek. Bandung: Alfabeta. 